\title{
Measures of Complementarity and Compatibility in Strategic Alliances for Innovation: A Review of Literature
}

\author{
Ram Kumar Dhurkari \\ Doctoral Student, IT and Systems Department \\ Indian Institute of Management, Kozhikode \\ Kerala, India 673570 \\ ram_dhurkari@rediffmail.com \\ M. K. Nandakumar \\ Associate Professor, Strategic Management Department \\ Indian Institute of Management, Kozhikode \\ Kerala, India 673570 \\ nandakumarmk@iimk.ac.in
}

\begin{abstract}
By focusing on resource-based view (RBV) and dynamic capability view (DCV), a target firm can be assessed for its complementarity and compatibility by the alliance-initiating firm to form a strategic technology alliance. This is because complementarity and compatibility among the partner firms affect the alliance performance. By reviewing the empirical findings on innovation through strategic alliances, this paper helps to classify various innovative capabilities possessed by a target firm as measures of complementarity or compatibility. This classification has several implications for researchers and practitioners dealing with the problem of partner selection for innovation in strategic alliances.
\end{abstract}

Keywords: Complementarity, Compatibility, Strategic Alliances, Innovation

\section{Introduction}

Today, with the increase in competition, firms are continuously attempting for competition through cooperation, especially in the high technology sector. Various authors recognized a fundamental shift from traditional form of competition between firms (firm vs. firm) to a new form of competition between strategic alliances (group vs. group) comprising of different firms ${ }^{1-3}$. Ref. 4 is among the first to explore the increase in frequency of technology collaboration. The multiple collaborative agreements make different firms compete intensely with each other in their core areas, resulting into 'co-opetition' behavior'. Several studies found a positive impact, and inverted $\mathrm{U}^{8-12}$ relationship between technology alliance portfolio diversity and financial performance via increased product innovation performance. When firms use alliances as one of the instruments to survive in a competitive environment, it creates another level of competition to have access to better partners and their resources ${ }^{13}$.

Various studies suggest that factors like complementarity, compatibility and commitment of partners contribute to the success of an alliance. Although, there may be two or more firms involved in mutual negotiation for forming alliances, the decision to partner is typically initiated by one firm $^{14}$. Detailed partner assessment by the alliance-initiating firm can lead to greater success ${ }^{15}$. Target firms are assessed in terms of their innovative capabilities before forming a strategic alliance for innovation. Since the target firms possess various innovative capabilities, the allianceinitiating firm needs to correctly classify various innovative capabilities possessed by the target firms either as a measure of complementarity or compatibility. It is equally important to examine whether an innovative capability should be considered as a measure of complementarity or compatibility in the assessment of 
target firms. This is because in certain situations, the complementarity among partners may be of much more importance than the compatibility or vice versa. In this study, we review the empirical work on innovation in strategic alliances and use its findings to classify various innovative capabilities of the target firm like organization capital, human capital, learning orientation, absorptive capacity, social capital and R\&D capability as a measure of complementarity or compatibility. By following prescriptions from the literature, we argue that if the possession of a particular innovative capability by both the partners is leading to the success of the alliance or of its superior performance, this particular innovative capability can be considered as a measure of compatibility. Similarly, those differences in innovative capabilities of the partner firms leading either to the success of an alliance or its superior performance can be considered as measures of complementarity. This classification is useful to researchers for developing new research questions and for practitioners in properly assessing target firms before forming strategic alliances.

This paper is organized into eight sections. In second section, we discuss various motivations of firms to form strategic alliances, especially for innovation. Third section discusses the factors relating to complementarity and compatibility of alliance partners. In fourth section, we discuss the relationship between innovative capabilities of firms and their performance. Section 5 classifies various innovative capabilities of a target firm as a measure of complementarity or compatibility. Implications of this classification are discussed in the section six. Section 7 discusses limitations of the classification and future research directions. Finally, section seven concludes the paper.

\section{Strategic Alliances and Innovation}

Strategic alliance is a cooperative agreement between two or more partner firms intended to affect the longterm product market position of at least one partner ${ }^{16}$. In the last couple of decades, many firms have used strategic alliance as a key growth strategy ${ }^{15}$. Firms generally have different motivations or objectives for forming alliances. These motivations include enhancing market power ${ }^{17,18}$, acquiring and exchanging skills ${ }^{4,18-20}$, increasing efficiencies ${ }^{21}$, gaining economies of scale and $\operatorname{scope}^{22,23}$, getting access to new and critical resources or capabilities ${ }^{24}$, sharing risk and investment ${ }^{25,26}$, facilitating strategic renewal ${ }^{27}$, entering new markets ${ }^{28}$, achieving innovation and market performance ${ }^{29}$ and acquiring various kinds of legitimacy ${ }^{30}$. There are various means to increase access to the resources possessed by other firms, for example mergers and acquisitions. However, alliances offer faster and cheaper route to achieve this ${ }^{31}$. Further, in the context of transaction-cost reasoning, alliances are preferred over acquisitions when the needed asset is specific, access cost is prohibitive and uncertainty exists over the assessment of performance of the target firm ${ }^{32}$. Ref. 33 studied alliance formation of fortune 1000 companies and found that CEO's of $80 \%$ of companies believed that alliances generate around $26 \%$ of their companies' revenues. Increasingly, it has been shown by scholars ${ }^{34,35}$ that strategic alliances are also being used as a means to learn and understand new business environments. Ref. 36 has identified 15 reasons explaining why firms might enter into a strategic alliance.

However, the failure rate of alliances is also very high $^{37}$. Literature suggests that approximately $30-70 \%$ of strategic alliances failed because they neither helped the partner firms to achieve their goals, nor provided them any operational or strategic benefits ${ }^{38}$. Approximately $50 \%$ of these alliances was terminated eventually ${ }^{39}$. In few cases, alliances even resulted into value destruction of the shareholders of parent companies ${ }^{40}$.

Coming to the strategic technology alliances, Ref. 41 define strategic technology alliance as "cooperative agreements for reciprocal technology sharing and joint undertaking of research between independent actors that keep their own corporate identity during the collaboration". There are various motivations to go for a strategic technology alliance like reduction in cost and risk associated with $\mathrm{R} \& \mathrm{D}$, transference of technology in order to improve innovation performance, reduction in time-to-market and search for new technological opportunities $^{41}$. Two of the most common explanations for forming inter-organizational ties are interdependence and complementarities ${ }^{42-44}$. The external resource scarcity is the most important reason for engaging in collaborative agreements45 (Park, Chen, and Gallagher, 2002). Acquisition of new technical skills or technological capabilities of partner firms is another important motivation for forming technology 
collaborations $^{4,46-50}$. Since the firm specific technological capabilities reside in the form of tacit knowledge, forming alliance is a better instrument to gain access to such capabilities. Because of rapid technological change, new knowledge expires quickly in high technology industries, which demand quick strategic response and timely learning. Such strategic response and timely learning is possible through strategic alliances in comparison to other forms of formal and hierarchal control mechanisms ${ }^{16,17}$.

Further, Ref. 51 carried out a study on the preferences that companies have in using alternative sources of innovative competencies such as strategic technology alliances, mergers and acquisitions or a mix of these. They found that companies that are operating in the high technology sector, strategic technology alliance are a preferred mechanism for acquiring external innovative capabilities. Forming a technology alliance improves the functioning of partner firms and creates breakthrough innovations ${ }^{52}$. For example, Ref. 41 demonstrated a positive relationship between entry into technology alliances and the rate of innovation. However, the success of an alliance largely depends upon careful and detailed assessment of the target firms by the alliance-initiating firm ${ }^{53}$.

\section{Complementarity and Compatibility of Partner Firms in Strategic Alliances}

To take advantage of each other, firms rush to form alliances and often fail to account for the negative effects of poor partner selection ${ }^{4,53}$. The success of an alliance is largely depends upon smart partner selection $^{53}$. Firm characteristics often affect their chances for being selected by alliance initiating firm in forming strategic alliances and in turn affects the success of such alliances ${ }^{54-58}$. Alliance evolution has three main stages 1) formation phase, 2) design phase and 3) post formation phase. The success of an alliance depends upon certain critical factors at each stage of evolution ${ }^{59}$. For instance, partner selection is critical in alliance formation phase, setting up the appropriate governance structure is critical in alliance design phase and managing alliance continuously to realize value is important in post formation phase ${ }^{60}$.

Partner selection requires assessment in terms of relative attractiveness of target firms ${ }^{14}$. This attractiveness for example depends upon to what extent the target firm can enhance the financial value of the alliance or of the alliance-initiating firm, thus providing strategic advantages ${ }^{61-64}$. This attractiveness is also depends upon the degree to which an alliance-initiating firm evaluates the target firm as desirable, favorable, appealing and valuable. More attractive a target firm is, more are its chances of being chosen by the allianceinitiating firm for forming strategic alliances ${ }^{14}$. Smart partner selection is also important because lack of good strategic fit between partner firms may lead to alliance failure $^{65}$. Ref. 66 distinguishes between theoretically important notions of task-related criteria and partnerrelated criteria used by various firms for partner selection. The former includes operational skills and resources which a venture requires for its competitive success, including patents and technical expertise, financial resources, experienced managerial personnel, and access to marketing and distribution systems. The later refers to the efficiency and effectiveness of partner's cooperation, which includes partner's national or corporate culture, size or structure, the degree of favorable past association between the partners, compatibility and trust between partners' top management team.

Ref. 14 reviewed more than 40 studies and found three major partner traits that play a critical role in the success of a strategic alliance. These partner traits are partner complementarity, partner compatibility or fit and partner commitment. Partner complementarity is the measure of non-overlapping resources that the partners bring to the alliance relationship. If the partner firms are similar in terms of strategic resources and competitive postures, it may lead to higher direct competition between them ${ }^{67-69}$. Ref. 58 labels this competing similarity as Type I diversity indicating how similar two partners are in their possession of strategic resources and skills. The lesser is the difference, less they have to offer to each other and greater is the likelihood of competition between them. Too much similarity in terms of resources could limit the alliance benefits ${ }^{70}$ and partners may find themselves actually competing rather than cooperating ${ }^{56}$.

Partner compatibility refers to the fit between firms in terms of factors like working styles and culture. An alliance between similar firms is expected to be successful than asymmetric firms ${ }^{55,71}$. Ref. 58 labels this cooperating similarity as Type II diversity. This kind of similarity leads to attraction causing attitudes to become positive, leading to favorable outcomes ${ }^{72,73}$. 
Partner commitment is the willingness of the partners towards contributing required resources to the alliance and sacrificing short-term gains against longterm success of the alliance ${ }^{74}$. Partner complementarity and partner compatibility can be analyzed during partner selection process while partner commitment can be evaluated only during post formation phase. Since this paper is about partner selection process, we focus only upon partner complementarity and partner compatibility. Since this paper considers the resource based view and the dynamic capability view of firm, we will also analyze how the complementarity and the compatibility between the partner firms affect the performance of a strategic technology alliance. The paper also examines which innovative capabilities can provide measure for assessing complementarity and compatibility of target firms in partner selection process for forming strategic technology alliances.

\section{Innovative Capabilities and Firm Performance}

Technology and innovation must be managed. Technology is one of the resources that require alignment with the overall organizational strategy. Competition and rapid changes in the technological paradigms require improvement in the organization's innovation and its innovative capability. The resource based theory of the firm ${ }^{75-77}$ and the dynamic capability view of the firm ${ }^{78}$ emphasizes the importance of unique innovative capabilities, which create sustained competitive differences among various firms. These two distinct views help in assessing firms in terms of their innovative capabilities. The resource-based view reflects the resources available in the organization to develop and exploit its innovative capability. The resource-based view includes the way firms secure factors needed to create the core competencies and capabilities which can be the basis for establishing and sustaining competitive advantage. Coming to dynamic capability view, Ref. 79 define dynamic capabilities as "the firm's ability to integrate, build and reconfigure internal and external competences to address rapidly changing environments". Such capabilities evolve over time.

Innovative capabilities can be defined as the comprehensive set of characteristics of an organization that facilitates and supports innovation ${ }^{80}$. Ref. 80 proposed an innovation audit framework for assessing innovative capabilities of an organization in terms of five important classes of variables 1) Understanding competitor's innovative strategies and multi-industry evolution 2) Understanding corporate technological environment 3) Corporate strategic management capacity 4) Resource availability and allocation 5) Corporate structural and cultural context. A combination of these variables is able to determine the relative strength of an organization in formulating and implementing innovation strategies. Since we are considering only the resource-based view and the dynamic capability view of a firm, we ignore the first three variables and focus only on the other two.

Out of the two selected classes of variables, the "Resource availability and allocation" includes measures like breadth and depth of skills at business unit level in $R \& D$, engineering and market research, distinctive competencies in the areas of technology relevant to the business unit and $\mathrm{R} \& \mathrm{D}$ funding. Business Unit structural and cultural context includes measures like mechanisms for managing R\&D efforts, transferring technology from research to development, integrating different functional groups in the new product development process and for eliciting new ideas from employees.

The internal R\&D capability of a firm, which measures the technology expertise and $R \& D$ investments, has a positive impact on innovation output $^{81}$ and financial performance ${ }^{82}$ of the same firm. Continued investment in R\&D creates in-house research capability for developing new technology or by assimilating it from outside ${ }^{83}$. Such R\&D capabilities are valuable, rare, inimitable and non-substitutable resource for superior innovation performance ${ }^{75,84,85}$. Significant R\&D capability of a firm increases the effectiveness of its intellectual human capital because of better research facilities, cultural norms and processes ${ }^{86}$. The human intellectual capital of the firms is also found to be closely associated with their innovation output (for example Ref. 81, 86). Scholars have shown the effect of a firm's ability to manage and utilize knowledge resources on its innovation output. In order to accumulate and utilize knowledge, organizations adopt different approaches that are determined by different aspects of intellectual capital, namely human, organizational and social capital ${ }^{87-89}$. Human capital is defined as the "knowledge, skills, and abilities residing with and utilized by individuals" ${ }^{\prime \prime 9}$, whereas 
organizational capital is the "institutionalized knowledge and codified experience residing within and utilized through databases, patents, manuals, structures, systems, and processes" "90. The third aspect, namely social capital is defined as "the knowledge embedded within, available through and utilized by interactions among individuals and their networks of interrelationships" ${ }^{\prime 88}$.

Innovations can either be incremental or radical ${ }^{91}$. Incremental innovation improves existing products, services, or technologies but reinforces existing design and technologies. However, radical innovations are major transformations of the existing products, services, or technologies. Radical innovations do not reinforce the existing design and technology, but rather makes them obsolete ${ }^{92}$. Ref. 93 observed that the incremental innovation involve "improving and exploiting an existing technological trajectory" whereas radical innovation involves "disruption in an existing technological trajectory". Ref. 94 noted that the incremental innovation "build on and reinforce the applicability of existing knowledge" while the radical innovation "destroy the value of an existing knowledge base". Thus, the incremental and radical innovation both draws organizational knowledge differently. Incremental innovation draws reinforced existing knowledge and often requires improvement and updating of this existing knowledge, whereas radical innovation requires transformed knowledge and makes the existing knowledge obsolete. This transformation of knowledge could be either addition of knowledge or morphing old knowledge into something new. It is found that the organizational capital (organizational knowledge) possessed by the firms is positively related to their incremental innovative capability ${ }^{95}$. Ref. 96 identified convergence between the domain knowledge an organization possesses and the knowledge of fresh patenting activities.

The human capital describes a firm's propensity for access and exposure to diverse knowledge domains. Creative and bright human individuals can become sources of new ideas and knowledge for innovation ${ }^{97,98}$. Ref. 81 in their study found that the firms maintain a significant level of intellectual human capital to produce more innovations. Such human individuals are also found to be flexible in acquiring new skills ${ }^{99}$. Radical innovations require tying of ideas of those individuals to one another. According to Ref. 95, one of the key attributes of social capital is ties and links. The sharing of information and knowledge can be encouraged with the help of these ties and links. Thus, if human capital can generate new ideas and knowledge, social capital can connect them to achieve radical breakthroughs. The greater the social capital in an organization, stronger will be the influence of human capital on radical innovative capability ${ }^{95}$. In addition, the higher the innovativeness of a firm, greater will be its performance 100,101 .

Further, innovation is also strongly related to a firm's absorptive capacity and learning orientation. Ref. 102 defines the concept of absorptive capacity as a "firm's ability to evaluate, assimilate and apply new external knowledge to a firm's operational environment". The ability to evaluate and utilize outside knowledge depends upon a firm's prior related knowledge ${ }^{102}$. The absorptive capacity of firms is positively related to their innovation efforts ${ }^{103}$, innovation output ${ }^{104}$ and performance ${ }^{104-106}$. Ref. 107 found a positive relationship between the absorptive capacity of firms (small and medium enterprises) and their performance.

The learning orientation of an organization refers to the activities for creating and using knowledge within and across the organization. Ref. 108 shown that the organizational learning helps firms to develop new knowledge repositories and is crucial to their innovation capability and performance. Learning orientation determines what kind of information the organization gathers $^{109}$, how it is interpreted ${ }^{110}$, evaluated ${ }^{111}$, and shared $^{112}$. Extensive empirical evidences suggest that learning orientation and organizational learning positively influences financial and non-financial performances of the individual firms ${ }^{57,113-115}$.

Learning also requires an effective and efficient system of information sharing. Such a system would help an organization to prepare a single repository of information and knowledge and learn from the accumulation of individual learning. The loss of knowledge due to employee turnover or transfer can also be minimized with the appropriate management of such knowledge repositories ${ }^{116}$. However, even if an organization has a shared vision and is committed to learning, the learning cannot be achieved until and unless the organization has an accumulation of knowledge $^{112}$. Some recent studies suggest that the organizational learning is positively related to firm 
performance, contingent upon the factors like organization's age ${ }^{117}$ and the governance mechanisms ${ }^{118}$. Figure 1 explains the relationship between various innovative capabilities of a firm and its innovativeness and performance.

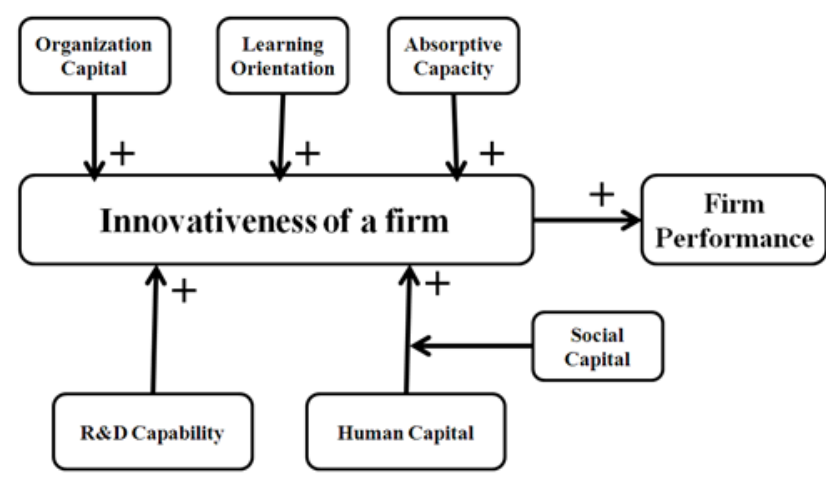

Fig. 1. Innovative Capabilities and Firm Performance

\section{Innovative Capabilities as a measure of Complementarity or Compatibility}

The discussion presented in previous sections clearly indicates that the complementarity and the compatibility among partner firms are very critical for the success of an alliance. The extant literature relied on a variety of objective and subjective measures to assess the performance or success of an alliance, namely financial results $^{22,23,119}$, survival ${ }^{120}$, duration ${ }^{121,122}$, perceived satisfaction $^{123,124}$, motivations for learning ${ }^{125}$, improve in strategic positioning ${ }^{22}$ and inter-firm trust ${ }^{126,127}$. For a thorough analysis, see Ref. 128 and Ref. 129.

Resource based theories suggest a direct positive relation between success of an alliance and the complementarity among alliance partners and studies have found support for this. Partner complementarity actually provides assurance about the outcomes even if it is difficult to assess the outcomes initially ${ }^{14}$. The competing similarity between alliance partners is negatively related to alliance performance ${ }^{72}$. In addition to partner complementarity, partner firms must be compatible for alliance formation and success ${ }^{130}$. The greater the cooperating similarity, higher will be the expected performance levels ${ }^{72}$. Similarly, the corporate culture and similarity in management practices among alliance partners is positively related to the performance of such alliances ${ }^{72}$. Therefore, there is a positive effect of complementarity and compatibility among partner firms on the performance of a strategic alliance (Figure 2).

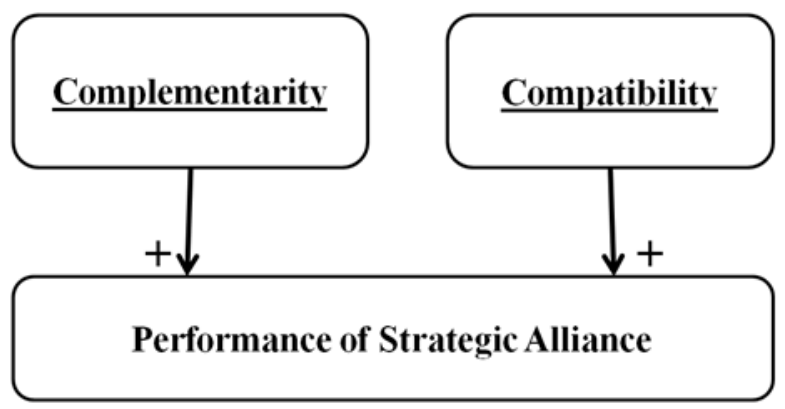

Fig. 2. Complementarity and Compatibility among partner firms effecting alliance performance

We have discussed the effects of various innovative capabilities on a firm's innovation output and on its performance. Broadly, we can classify various innovative capabilities into two classes' namely tangible resources and intangible resources. Tangible resources include the physical infrastructure, financial capability, number of patents, technological position and capabilities, and organizational capital. Intangible resources include the absorptive capacity of the firm, learning orientation of the work force and the organization, social capital, resource coordination, person's coordination, ability to manage and utilize knowledge resources, and knowledge transfer capacity. These innovative capabilities can be considered either as a complementary measure or a compatibility measure for the partner selection in a strategic technology alliance. Studies have shown that possession of these innovative capabilities affects the innovation output and ultimately the performance of a firm. By assessing the extent of meeting the targets or the objectives (in terms of superior benefits, superior financial performance of partners, greater organizational learning and knowledge transfer among the partners) the success of a strategic alliance can be measured. A strategic alliance is considered successful when the partners are mutually benefited. Therefore, by following prescriptions from the literature, we argue that if the possession of a particular innovative capability by both the partners is leading to the success of the alliance or of its superior performance, this particular innovative capability can be considered as a measure of compatibility. Similarly, those differences in innovative capabilities of the partner firms leading either to the success of an alliance or its superior performance can be considered as 
measures of complementarity. In order to verify these arguments, we now refer to some empirical studies on strategic alliances for innovation and their findings.

\subsection{Technological Domain and Human Capital}

When the innovation output of two firms is similar, they occupy structurally equivalent positions and will appear very near to each other in a technology network. A technology network provides the relative position of various firms with respect to their domain of technology operation and their competencies. Such firms even can substitute each other in their innovative roles. Patent overlaps or the number of patents in various technology domains can also help to identify position of firms in a technology network. The number of patents secured by a firm is an externally validated measure of innovation output and represents the technological competence of a firm ${ }^{131}$. These patenting records are closely related to the stature of the firm in a technical arena ${ }^{131,132}$. Firms possessing patents in the same technological domain will be close to each other in a technology network. Ref. 96 studied the technological position of firms and their chances of forming alliances. The results of their study indicate a positive association between the propensity of a firm to form alliances and the degree to which it innovates in technological fields that are not directly associated with those in which it has developed technologies in the past. In addition, the past technological capabilities also determine the position of the firm in a knowledge space. Knowledge space is used to identify the knowledge levels of various firms. The overlap between partner firms in knowledge space can be used to assess the similarity in organizational capital of the partner firms. Ref. 133 discuss about the knowledge assets possessed by the partners and their role in the success of knowledge creating alliances. Sharing of knowledge (including technology expertise and organizational capability) is found to be one of the dominant objectives of strategic alliances ${ }^{20,48,134-143}$. According to Ref. 133, there will be high chances of forming alliance by two firms if they have an optimal overlap in knowledge space. Studies have also found moderating effect of new product development process characteristics and external environmental factors on the relationship between knowledge complementarity of partners and alliance's new product innovativeness ${ }^{144}$.

However, as knowledge overlap among alliance partners' increases, the chances of separation also increase. Firms whose overlap is near optimum level have a high propensity of forming alliances. Over time, when partner firms involve themselves with joint activities, their knowledge overlap increases, making each other less attractive and the alliance dissolves. When two firms are distant in technological space and the knowledge space, they tend to form an alliance to learn from each other and increase the knowledge overlap $^{20,145}$. However, if the firms are too far apart, they may also face difficulty in understanding each other, sharing and recombining ${ }^{146,147}$. If the overlap is either very large or small, the cost of the alliance will exceed its expected benefits. Ref. 148 also found a similar inverted $\mathrm{U}$ relationship between knowledge base overlaps and innovation performance - not in strategic alliances but rather in acquisitions. Hence, as the distance between the partners in the technology network and knowledge space increases, greater will be their chances of forming a successful alliance. If the distance between the alliance partners is very low, they will not have much to offer to each other, resulting into fewer chances of successful alliance formation. Ref. 149 in their study found that that alliance portfolio with greater organizational and functional diversity is related to higher firm performance. According to Ref. 149, "the organization and functional diversity capture the learning and resource access benefits accruing from collaborating with diverse organizations for a wide scope of functional purposes". In addition, knowledge complementarity is positively related to firm learning ${ }^{150}$. Hence, the organizational capital (which includes technological position, technological capabilities, and patents) and human capital (knowledge and skills) can be considered as measures of complementary while assessing the attractiveness of a target firm for forming an alliance.

\subsection{Learning Orientation}

Going further, optimum knowledge overlaps among partner firms is not enough for the success of an alliance. What is more important is whether the human capital of the partner firms is able to learn from each other and increase the knowledge overlap. Learning in alliance situations can take place mainly in three ways. First, alliance partners can learn either by accessing or by internalizing some critical information, capabilities or skills, which are beneficial to the partners ${ }^{138}$. Second, they can learn to manage the collaboration process and 
relationships more effectively ${ }^{1,151}$ and third, they can learn to manage the alliance and its capability ${ }^{152,153}$. In this paper, we discuss only the first kind of learning which is more important in a strategic alliance for innovation and has been widely studied in the literature.

For a strategic alliance to succeed, the partners should not only learn from their own and increase their knowledge base, but should learn to learn together to make them interdependent ${ }^{72,154-155}$. Learning together requires that the partners must think and behave similarly ${ }^{155}$. This learning largely can be ascribed to the absorptive capacity of firms. Ref. 156 conceptualized absorptive capacity as "a broad set of skills needed to deal with the tacit component of transferring knowledge of the partner company and the need to modify this knowledge for the firm's own specific environment". Ref. 157 found that the increase in the absorptive capability of a firm improves its ability to exploit sources of technical knowledge outside its boundaries. Absorptive capacity affects the ability of partner firms to learn ${ }^{158}$ and develop new and competitive products to strengthen their financial performance. However, it is also found to depend upon the relationship characteristics between the partners ${ }^{159,160}$ and the alliance structure ${ }^{105}$.

However, literature has also reported some discouraging behaviors of partners. The transaction cost literature has emphasized the opportunistic behavior of partners in inter-organizational relationships, leading to learning race $^{138}$ between the partners. Using case studies, Ref. 4 indicated that the firm, which possesses a strong learning intentional and develops a learning environment, wins the race to learn. In such cases, partners face a challenge of balancing between trying to learn and trying to protect. Inter-partner relationships and trust in alliances or in exchange situations ${ }^{16,}$ 161-162 plays an important role in diluting these challenges. Ref. 137 demonstrated the existence of characteristics like level of mutual trust, respect and friendship through relationship capital of the alliance. The analytic framework developed by Ref. 138 describes the dynamics of learning race by showing that the firm's incentive to learn depends upon expected payoffs associated with such learning. Thus, the learning strategy adopted by a partner firm depends upon the motivation and capacity to assert its receptivity as well as on motivation and capacity to cooperate by being transparent ${ }^{139}$. Receptivity as defined by Ref. 163 "is the readiness of the learning partner to appreciate and receive the knowledge brought in by the teaching partner". This receptivity is also limited by learning intent of the firm ${ }^{4}$.

According to Ref. 164, the learning-oriented cooperative strategies involve a denser and a more varied set of inter-organizational interactions as compared to performance- oriented or output-oriented strategies. The motivation to learn is one of the major determinants of learning, resulting into the absorption of knowledge in the context of individual learning ${ }^{165-167}$ as well as in the context of inter-organizational setting such as strategic alliances ${ }^{4}$. Learning intent is found to be having the most decisive influence on the acquisition of specific competencies by alliance partners ${ }^{46,168,169}$. Ref. 4 argues that partner learning is a more powerful determinant of alliance success in comparison to its stability or longevity. The higher the learning intent of the partners, the higher will be the resource based learning capacity (commitment of human and tangible support assets), the cognitive based learning capacity (general attitude and behavior towards learning) and the knowledge transfer ${ }^{170}$. According to Ref. 171, knowledge transfer is the process by which one member in the network is affected by the experience of another member. Knowledge transfer is a result of organizational learning. Organizations, which are able to transfer knowledge, effectively from one organizational unit to another are found to be more productive than those who are less capable of doing so ${ }^{172-176}$. Social exchanges such as reciprocal commitment, trust and mutual influence among partners are positively associated with learning and knowledge transfer in strategic alliances ${ }^{177}$. However, the ease of learning and knowledge transfer may also be influenced by the type (e.g. Tacit or explicit) of knowledge $\mathrm{e}^{146,178}$.

Further, the literature has also identified two distinct dimensions of knowledge management, namely exploration $^{99}$ or knowledge generation ${ }^{179}$ and exploitation $^{99}$ or knowledge application ${ }^{179}$. Knowledge generation involves activities that increase an organization's stock of knowledge and knowledge application involves activities that deploy existing knowledge to create value. Building upon this, Ref. 160 argue that intensive inter-organizational learning is not necessary in the case of strategic alliances created for exploitation of existing technologies but is crucial for alliances created for exploring new technologies. 


\subsection{Social Capital}

In addition, the strength of network ties creates value in the social network ${ }^{180}$. Ref. 181 defines strong ties as "combination of the amount of time, emotional intensity, mutual confiding and reciprocal services". Strong ties expect trust and non-opportunistic behavior from the partners $^{180}$. Trust has important implications on the allied success and is defined as the expectation that individuals will fulfill obligations in predictable, fair and reliable ways ${ }^{182,183}$. Trust allows open access of information, stimulates collaboration and promotes cooperation $^{26,162,184-190}$ resulting in deeper access to information $^{88}$ thus, creating opportunities for learning. Strong ties (trust in one's contact) are positively related to learning of firms ${ }^{150}$. Mutual trust among partners is a major ingredient in the success or failure of a strategic alliance $^{32,151,161,191,192}$. Ref. 193 found that the trust between partners is positively related to learning among them and such learning is positively related to innovation. Trust is also positively related to international strategic alliance performance ${ }^{15,162,194-199}$. For a detailed review of the role played by trust in the context of strategic alliances, see Ref. 200.

\subsection{Absorptive Capacity}

Furthermore, learning not only depends upon access to information, but the ability or absorptive capacity of firms and the individuals within it. This absorptive capability depends upon the knowledge gained by the partner firms, accumulated over the years and its relatedness with the external knowledge. Though some level of complementarity or diversity in knowledge is required for learning ${ }^{201}$, some basis of relatedness is necessary to facilitate communication and exchange of ideas among partner firms ${ }^{102,158,202,203}$. Further, the differences in human capital allocated and embodied by the partners have the power to influence their learning process. The individual's ability to utilize new knowledge depends upon his/her own level of expertise within a specific domain ${ }^{150}$. This expertise develops over a period with the extensive involvement of individuals in understanding and developing a repository of knowledge. As a result, individuals with high level of expertise easily assimilate information and link it to their existing knowledge, enabling them to solve problems quickly and effectively in comparison to those having a lower level of expertise ${ }^{204}$. Ref. 150 found that a positive relationship between an individual's expertise and firm learning is stronger for large firms and weaker for smaller ones. Ref. 205 found that the knowledge acquisition and knowledge creation both enhance innovative performance.

Moreover, the pre-alliance relationship between the patent portfolios of partner firms also found to affect the ability of such firms to absorb the technological capabilities from its partners ${ }^{145}$. Ref. 206 found that the relationship between organizational learning and performance of the partners is stronger in joint ventures and in those alliances where the scope of collaborative activity is broader than in the case of contractual alliances. Innovation is considered to be positively related to learning in international strategic alliances ${ }^{193}$. However, innovations are also possible without learning (knowledge transfer) because innovations are often made up of dissimilar knowledge bases, which may best be maintained in separate organizations ${ }^{207}$. According to the findings of Ref. 193, the learning and innovation in international strategic alliances are influenced by a firm's ability (expertise) and the willingness (protectiveness) to transfer knowledge and are mediated by the codifiability and transferability of knowledge to be shared (tacitness) and the quality of the relationship (trust). Therefore, the more is the absorptive capacity of partner firms, more will be learning from each other and the greater will be the success of the alliance ${ }^{208-210}$. The lack of organizational fit between the partners in terms of culture, processes and systems in place may lead to the failure of a strategic alliance ${ }^{137}$. Ref. 211 studied the impact of three indicator of technology strategy relevant to absorptive capacity on the innovation performance. The three indicators are proportion of $R \& D$ alliance in an alliance portfolio, technological distance and $R \& D$ intensity. They found positive relationship between R\&D intensity and innovative outcomes. It is generally argued that when partners are similar in characteristics and routine, there will be more effective knowledge transfer and easier communication, which will benefit inter-organizational collaboration. Certain degree of absorptive capacity is required for effective learning in inter-organizational collaborations ${ }^{212,213}$. Therefore, the learning orientation, social capital and absorptive capacity of partner firms can be considered as measures of compatibility between the partner firms. 


\subsection{R\&D Capability}

Coming to tangible resources possessed by partner firms, the R\&D capability of a firm can be attributed to the possession of assets, financial strength and physical infrastructure. Ref. 214 has found that the greater the technological capabilities of a high-tech firm alliance partner, higher will be the rate of innovation of that firm. Ref. 214 studied the effect of firm level characteristics (namely technological competencies, innovativeness, extent of market coverage, substantial stock of technological resources and the size) on the performance of the partner firms and the success of the alliance. Ref. 214 found that in technology alliances, large, innovative firms helped their partners to improve their baseline innovation and growth rate while small and unsophisticated partners had very slight or immaterial effect on the other partners. Ref. 214 also studied the alliance formation between a young and small firm with an old and large firm and found that having a highly innovative partner has greater benefit of the former than to the later type of firms. However, an alliance is considered successful when the partners are mutually benefited. Research has shown that the attractiveness of a firm for alliance formation is positively related to the resources possessed by it $^{17,215-}$ 217 because alliances are often used as a means to acquire the valuable resources possessed by other firms. Most of the existing literature considers resource alignment of partners only in terms of resource similarity. However, Ref. 128 derives four types of inter-partner resource alignments using the dimensions of resource similarity and resource utilization namely supplementary (similar-performing), surplus (similarnon performing), complementary (dissimilarperforming) and wasteful (dissimilar-non performing). Supplementary and complementary resource alignments have significant impact on the collective strength of an alliance $^{128,218-220}$.

Therefore, the greater the R\&D capabilities of a high tech firm's alliance partner, the higher will be the rate of innovation. In addition, the greater the innovativeness of the partner firms, greater will be the innovativeness and the chances of success of the alliance. Ref 221 and 222 found positive effects of similarity of partners in their technical assets for successful cooperation in joint ventures. Thus, $R \& D$ capability can be considered as a compatibility measure for partner selection in strategic alliances for innovation. Figure 3 provides the classification of various innovative capabilities of partner firms as measures of complementarity and compatibility, which positively influence the performance of a strategic technology alliance.

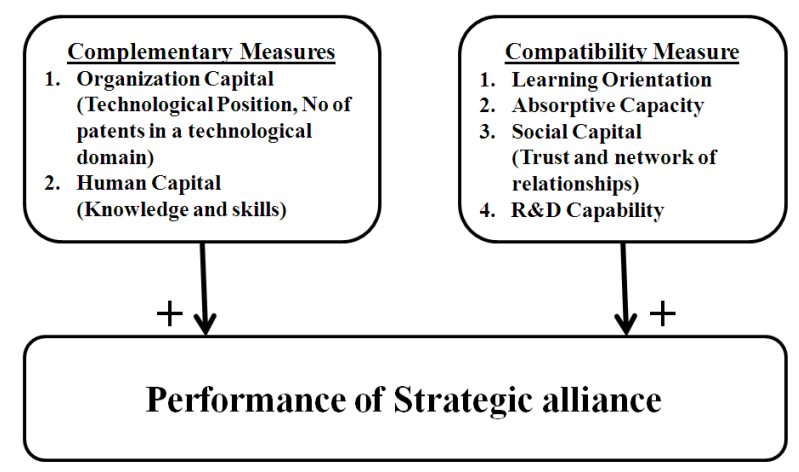

Fig. 3. Innovative Capabilities as measures of Complementarity and Compatibility

\section{Implications}

Alliance partner selection for innovation is a discrete alternative multi-criteria decision problem in which the target firms are the alternatives and the innovative capabilities are the criteria for evaluation ${ }^{223,224}$. However, it is equally important to examine whether an innovative capability should be considered as a measure of complementarity or compatibility in the assessment of target firms. This is because in certain situations, the complementarity among partners may be of much more importance than the compatibility or vice versa. For example, Ref. 224 identified various motivations for forming strategic alliances (strategy oriented, cost oriented, resource oriented and learning oriented) and proposed a multi-criteria framework considering these motivations. It is likely that the technology-oriented motivations may give more importance to the complementarity of the target firm than to its compatibility. Similarly, learning oriented motivations may emphasize the compatibility more than the complementarity. Ref. 66 and Ref. 120 distinction of task-related criteria and partner-related criteria used by various firms for the selection of alliance partners may also differently emphasize the complementarity and the compatibility of the target firm with the allianceinitiating firm. The classification presented in this paper is helpful to researchers exploring partner selection traits in strategic alliances for innovation. 


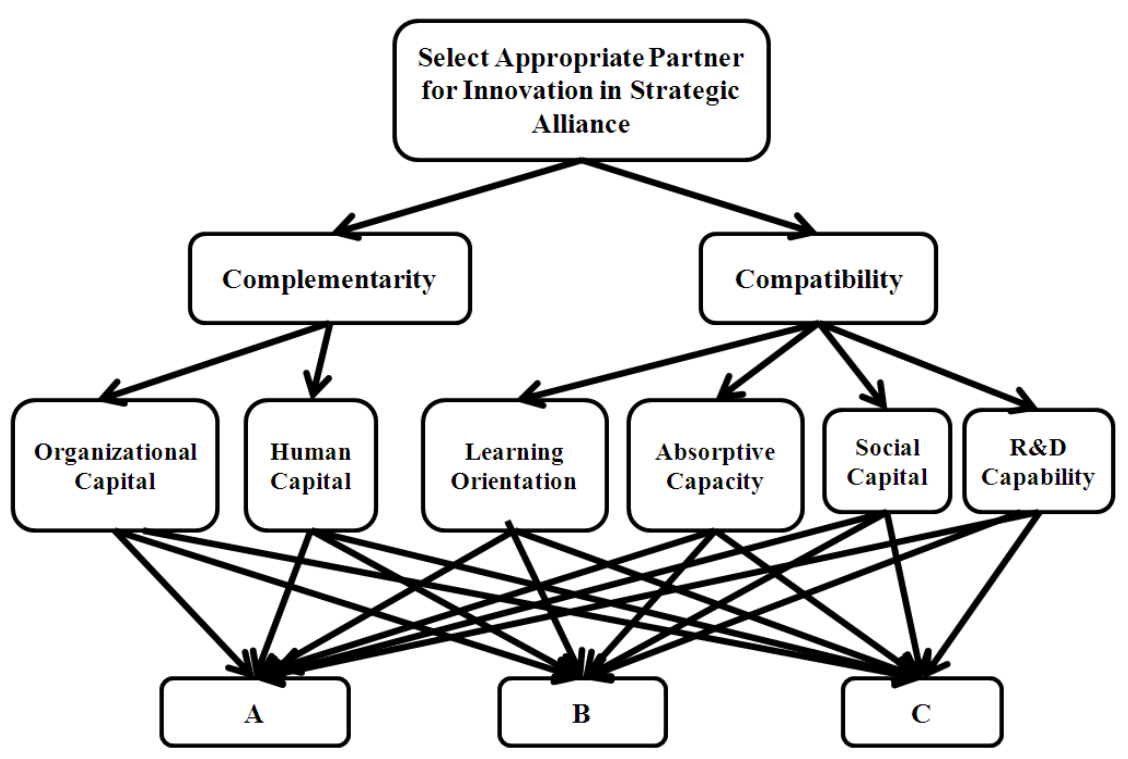

Fig. 4. Multi-Criteria Decision Hiarrarchy for partner selection problem

\section{Limitations and Future Research Directions}

This paper suggests a classification of few of the innovative capabilities as measures of complementarity or compatibility. Organizational capital and human capital are classified as measures of complementarity, while learning orientation, absorptive capacity, social capital and R\&D capability are classified as measures of compatibility. This paper focused on strategic technology alliances from various industries including information technology, pharmaceutical etc. Firms possess various innovative capabilities and that too differ in various innovation context. Future research can strive to identify other innovative capabilities that are important in specific innovation context.

Further, Ref. 223 and Ref. 224 had proposed two frameworks based on the Analytic Network Process (ANP) and the Analytic Hierarchy Process (AHP) and their applications for the assessment of target firms for innovation in strategic alliances. Both AHP and ANP are well-established multi-criteria decision-making (MCDM) methods. AHP is a theory of ratio scale estimation and is a special case of the Analytic Network Process (ANP). When using AHP, the multi-criteria decision problem is structured in the form of a hierarchy. The hierarchy begins with the overall objective of the problem at the top, followed by the criteria (and sub-criteria) and the alternatives at the bottom. The flow of influence is assumed top to bottom in comparison to ANP where it can be all around. Both methods capture the preference of the decision maker (DM) and synthesize them in order to generate a preferred rank order of alternatives.

Furthermore, if the DM knows the distinction between various innovative capabilities (as either a complementarity or a compatibility measure), he/she will be in a better position to judge the target firm as per the expectations or motivations to form of the strategic alliance. Some of these innovative capabilities must be considered as measures of complementarity while the others as measures of compatibility. Listing out all the innovative capabilities of target firms and selecting a partner firm without giving varied importance to complementarity and compatibility may result into poor partner selection, which might affect the outcomes of the strategic alliance. Based on the discussion in this paper, we suggest that there should be an intermediate level in the decision hierarchy of partner selection problem for innovation in a strategic alliance. For example, see the decision hierarchy in Figure 4 where three target firms (A, B, C) are to be assessed for forming a strategic alliance. The DM needs to define the importance of expected complementary and compatibility along with other relevant criteria when assessing the target firms. Given a decision situation, the DM can give preferences not only in terms of alternatives and their innovative capabilities, but also the expectations of the alliance-initiating firm in terms 
of the importance to complementarity and compatibility. Future research can examine the problem structure developed in the form of decision hierarchy (Figure 4) and apply various MCDM for partner selection in innovation in strategic alliances.

\section{Conclusion}

The performance of an innovative firm can be judged by its innovative capabilities. Since a single firm may find difficulty in carrying out innovation and bearing the cost and the risk associated with new technology development, alliance are used by firms to gain access to various innovative capabilities of other firms. Selecting a firm to form an alliance for innovation requires proper assessment in terms of innovative capabilities. Some of these innovative capabilities must be considered as measures of complementarity while the others as measures of compatibility. By extensively reviewing the existing literature, this paper advances the view that various innovative capabilities can be classified as measures of complementarity or compatibility. Listing out all innovative capabilities of a target firm and measuring its complementarity and compatibility by the alliance-initiating firm helps in intelligent partner selection, which subsequently can lead to superior performance of the alliance.

\section{References}

1. Y. Doz, The evolution of cooperation in strategic alliances: Initial conditions or learning processes, Strategic Management Journal Summer Special Issue. 17 (1996) 55-84.

2. B. Gomes-Casseres, Group versus group: how alliance networks compete, Harvard Business Review. 72 (1994) 62-70.

3. B. Gomes-Casseres, The Alliance Revolution: The New Shape of Business Rivalry (Cambridge, MA: Harvard University Press 1996).

4. G. Hamel, Competition for competence and inter-partner learning within international strategic alliances, Strategic Management Journal, Summer Special Issue. 12 (1991) 83-103.

5. R. Gnyawali Devi, and R. Madhavan Cooperative Networks and Competitive Dynamics: A Structural Embeddedness Perspective, The Academy of Management Review. 26(3) (2001) 431-445.
6. D. Faems, Matthias De Visser and P. V. Andris, Technology Alliance Portfolios and Financial Performance: Value-Enhancing and Cost-Increasing Effects of Open Innovation, Journal of Product Innovation Management. 27(6) (2010) 785-796.

7. C. C. Phelps, Longitudinal Study of the Influence of Alliance Network Structure and Composition on Firm Exploratory Innovation, Academy of Management Journal. 53(4) 890-913.

8. H. Bapuji, D. Loree and M. Crossan, Connecting external knowledge usage and firm performance: an empirical analysis, Journal of Engineering and Technology Management. 28 (2011) 215-231.

9. J. Chen, Y. F. Chen and W. Vanhaverbeke, The influence of scope, depth, and orientation of external technology sources on the innovative performance of Chinese firms, Technovation. 31 (2011) 362-373.

10. G. Duysters and B. Lokshin, Determinants of alliance portfolio complexity and its effect on innovative performance of companies, Journal of Product Innovation Management. 28 (2011) 570-585.

11. L. A. G. Oerlemans, J. Knoben and M. W. Pretorius, Alliance portfolio diversity, radical and incremental innovation: The moderating role of technology management, Technovation. 33 (2013) 234-246

12. G. Vasudeva and J. Anand, Unpacking absorptive capacity: a study of knowledge utilization from alliance portfolios, Academy of Management Journal. 54 (2011) 611-623.

13. J. A. C. Baum, T. Calabrese, and B. Silverman, Don't go it alone: Alliance network composition and startups performance in Canadian biotechnology, Strategic Management Journal Special Issue. 21 (2000) 267-294.

14. R. Shah and V. Swaminathan, Factors influencing partner selection in strategic alliances: The moderating role of alliance context. Strategic Management Journal. 29(5) (2008) 471-494.

15. P. Kale and H. Singh, Managing Strategic Alliances: What do we know now and where to go from here?, Academy of Management Perspective. August (2009) 4562.

16. J. Hagedoom, Understanding the rationale of strategic technology partnering: Interorganizational modes of cooperation and sectoral differences, Strategic Management Journal. 14(5) (1993) 371-385.

17. K. M. Eisenhardt, C. B. Schoonhoven, Resource-based view of strategic alliance formation: strategic and social 
effects in entrepreneurial firms, Organization Science. 7 (1996) 136-150.

18. B. Kogut, Joint ventures and the option to expand and acquire, Management Science. 37(1) (1991) 19-34

19. G. Huber, Organizational learning: The contributing processes and the literatures, Organization Science. 2 (1991) 88-115.

20. D. C. Mowery, J. E. Oxley and B. Silverman, Strategic alliances and inter-firm knowledge transfer, Strategic Management Journal Winter Special Issue. 17 (1996) 77-91.

21. G. Ahuja, Collaboration networks, structural holes and innovation: A longitudinal study, Administrative Science Quarterly. 45(3) (2000a) 425-456.

22. F. J. Contractor and P. Lorange, Why should firms cooperate? The strategy and economics basis for cooperative ventures, in Cooperative Strategies in International Business, eds. F. J. Contractor and P. Lorange, (Lexington, MA: Lexington Books. 1988) pp. 3-30.

23. J. Mohr and R. Spekman, Characteristics of partnership success: Partnership attributes, communication behavior, and conflict resolution techniques, Strategic Management Journal. 15 (1994) 135-152.

24. F. Rothaermel and W. Boeker, Old technology meets new technology: Complementarities, similarities and alliance formation, Strategic Management Journal. 29(1) (2008) 47-77.

25. E. Anderson, Two firms, one frontier: on assessing joint venture performance, Sloan Management Review. 31 (1990) 19-30.

26. P. Ring and A. Van de Ven, Structuring Cooperative Relationships Between Organizations, Strategic Management Journal. 13(7) (1992) 483-498.

27. B. Borys and D. B. Jemison, Hybrid arrangements as strategic alliances: theoretical issues in organizational combinations, Academy of Management Review. 14 (1989) 234-249.

28. E. Garcia-Canal, C. Duarte, J. Criado and A. Llaneza, Accelerating international expansion through global alliances a typology of cooperative strategies, Journal of World Business. 37(2) (2002) 91-107.

29. P. Ritala, Coopetition Strategy - When is it Successful? Empirical Evidence on Innovation and Market Performance, British Journal of Management. Vol. 23 (2012) 307-324.
30. J. A. C. Baum and C. Oliver, Institutional linkages and organizational mortality, Administrative Science Quarterly. 36 (1991) 187-218.

31. D. Lei, Offensive and defensive uses of alliances, Long Range Planning. 26(4) (1993) 32-41.

32. P. J. Buckley and M. Casson, A theory of cooperation in international business, In Cooperative Strategies in International Business, eds. F. Contractor, and P. Lorange, (Lexington, MA: Lexington Books 1988) pp. 31-53.

33. P. Kale, H. Singh and J. Bell, J.. Relating well: Building capabilities for sustaining alliance networks, In The network challenge: Strategies for managing the new interlinked enterprise, eds. P. Kleindorfer and Y. Wind, (London: Pearson Press 2009).

34. J. Child and A. P. Czegledy, Managerial Learning in the Transformation of Eastern Europe: Some Key Issues, Organization Studies. 17 (1996) 167-179.

35. H. K. Steensma and M. A. Lyles. Explaining IJV Survival in a Transitional Economy through Social Exchange and Knowledge-based Perspectives, Strategic Management Journal. 21 (2000) 831-851.

36. M. A. Hitt, R. D. Ireland and R. E. Hoskisson, Strategic Management: Competitiveness and Globalization. 2nd edn (St. Paul, MN: West publishing company 1997).

37. J. H. Dyer, P. Kale and H. Singh, How to make strategic alliances work, Sloan Management Review. 42(4) (2001) 37-43.

38. J. Bamford, B. Gomes-Casseres and M. Robinson, Envisioning collaboration: Mastering alliance strategies. (San Francisco: Jossey-Bass 2004)

39. R. Lunnan and S. Haugland, Predicting and measuring alliance performance: A multidimensional analysis, Strategic Management Journal. 29(5) (2008) 545-556.

40. P. Kale, J. Dyer and H. Singh, Alliance capability, stock market response and long-term alliance success: The role of the alliance function, Strategic Management Journal. 23(8) (2002) 747-767.

41. J. Hagedoorn and J. Schakenraad, The effect of strategic technology alliances on company performance, Strategic Management Journal. 15 (1994) 291-309.

42. C. Garcia-Pont and N. Nohria, Local versus global mimetism: the dynamics of alliance formation in the automobile industry, Strategic Management Journal. 23 (2002) 307-321.

43. J. Pfeffer and P. Nowak, Joint ventures and interorganizational interdependence, Administrative Science Quarterly. 21 (1976) 398-418. 
44. G. B. Richardson, The organization of industry, Economic Journal. 82 (1972) 509-518.

45. S. H. Park, R. R. Chen and S. Gallagher, Firm resources as moderators of the relationship between market growth and strategic alliances in semiconductor start-ups, Academy of Management Journal. 45 (2002) 527-545.

46. G. Hamel, Y. Doz and C. K. Prahalad, Collaborate with your competitors - and win, Harvard Business Review. 67(1) (1989) 133-139.

47. P. Mariti and R. H. Smiley, Co-operative agreements and the organization of industry, Journal of Industrial Economics. 31(4) (1983) 437-451.

48. A. Mody, Learning through alliances, Journal of Economic Behavior and Organization. 20 (1993) 151170.

49. W. Powell and P. Brantley, Competitive cooperation in biotechnology: Learning through networks?, In Networks and Organizations: Structure, Form and Action, N. Nohria and R. Eccles, eds., (Boston, MA: Harvard Business School Press 1992) pp. 365-394.

50. W. Shan, An empirical analysis of organizational strategies by entrepreneurial high-technology firms, Strategic Management Journal. 11 (2) (1990) 129-139.

51. J. Hagedoorn and G. Duysters,. External sources of innovative capabilities: The preference for Strategic Alliances or Mergers and Acquisitions, Journal of Management Studies. 39 (2002) 167-188.

52. Denise Dunlap-Hinkler, M. Kotabe and R. Mudambi, A Story of Breakthrough Versus Incremental Innovation: Corporate Entrepreneurship in the Global Pharmaceutical Industry, Strategic Entrepreneurship Journal. 4 (2010) 106-127.

53. C. J. Lambe and R. E. Spekman, The bases of alliance derived sustainable advantage: relationship and resources, American Marketing Association Winter Conference Proceedings. (1997) 119-125.

54. S. Chung, H. Singh and K. Lee, Complementarity, status similarity and social capital as drivers of alliance formation, Strategic Management Journal. 21 (2000)122.

55. K. R. Harrigan, Joint ventures and competitive strategy, Strategic Management Journal. 9(2) (1988) 141-158.

56. J. L. Johnson, J. B. Cullen, T. Sakano and H. Takenouchi, Setting the stage for trust and strategic integration in Japanese-U.S. cooperative alliances, Journal of International Business Studies. 27 (1996) 981-1004.
57. P. J. Lane, J. E. Salk and M. A. Lyles,. Absorptive capacity, learning, and performance in international joint ventures, Strategic Management Journal. 22(12) (2001) 1139-1161.

58. A. Parkhe, Inter firm diversity, organizational learning, and longevity in global strategic alliances, Journal of International Business Studies. 22 (1991) 579-601.

59. R. Gulati, Alliances and networks, Strategic Management Journal. 19(4) (1998) 293-317.

60. M. Schreiner, P. Kale and D. Corsten, What really is alliance management capability and how does it impact alliance outcomes and success?, Strategic Management Journal. 30(13) (2009) 1395 - 1419.

61. R. S. Achrol, L. K. Scheer and L. W. Stern, Designing successful trans-organizational marketing alliances, Report No. 90-118, Marketing Science Institute, (Cambridge, MA 1990) pp. 1-35.

62. J. H. Dyer, The determinants of trust in supplier automaker relationships in the U.S., Japan, and Korea, Journal of International Business Studies. 31(2) (2000) 259-285.

63. M. A. Hitt, D. Ahlstrom, T. M Dacin, E. Levitas and A. Svobodina, The institutional effects on strategic alliance partner selection in transition economies: China vs. Russia, Organization Science. 15(2) (2004) 173-185.

64. S. D. Jap, Pie-expansion efforts: collaboration processes in buyer-supplier relationships, Journal of Marketing Research. 36(4) (1999) 461-475.

65. W. A. Dymsza, Success and failures of joint ventures in developing countries: Lessons from experience, In Cooperative Strategies in international business, eds. F.J. Contractor, and P. Lorange (Lexington: Lexington Books 1988) pp. 403-424.

66. J. M. Geringer, Strategic determinants of partner selection criteria in international joint ventures, Journal of International Business Studies. 22 (1991) 41-62.

67. P. Dussauge and B. Garrette, Cooperative Strategy: Competing Successfully through Strategic Alliances, (Chichester: Wiley 1999).

68. P. Dussauge, B. Garrette and W. Mitchell, The market share impact of interpartner learning in alliances: evidence from the global automotive industry, In Cooperative Strategies and Alliances, F. J. Contractor, and P. Lorange, eds. (Oxford: Elsevier Science 2002) pp. 707-727.

69. B. Garrette and P. Dussauge, Patterns of strategic alliances between rival firms, Group Decision and Negotiation. 4 (1995) 429-452. 
70. T. Saxton, The effects of partner and relationship characteristics on alliance outcomes, Academy of Management Journal. 40 (1997) 443-461.

71. P. Lorange and J. Roos, Strategic Alliances: Formation, Implementation and Evolution, (Cambridge, MA: Blackwell 1992).

72. J. Kim and A. Parkhe, Competing and Cooperating Similarity in Global Strategic Alliances - an exploratory examination, British Journal of Management. 20 (2009) 363-376

73. P. M. Lazarsfeld and R. K. Merton, Friendship as a social process, In Freedom and Control in Modern Society, eds. M. Berger, T. Abel, and C. Page, (New York: Octagon Books 1954).

74. G. Gundlach, R. Achrol, and J. Mentzer, The structure of commitment in exchange, Journal of Marketing. 59(1) (1995) 78-92.

75. J. B. Barney, Firms resources and sustained competitive advantage, Journal of Management. 17 (1991) 99-120.

76. R. P. Rumelt, Toward a strategic theory of the firm, In Competitive Strategic Management, eds. R. Lamb, (Englewood Cliffs, NJ: Prentice Hall 1984) pp. 556-570

77. B. Wernerfelt, The resource-based view of the firm: ten years after, Strategic Management Journal. 16 (1995) 171-174.

78. R. Nelson, Why do firms differ, and how does it matter?', Strategic Management Journal. 12 (1991) 6174.

79. D. J. Teece, J. David, Gary Pisano, and A. Shuen, Dynamic Capabilities and Strategic Management, Strategic Management Journal. 18(7) (1997) 509-533.

80. R. Burgelman, M. A. Maidique and S. C. Wheelwright, Strategic Management of Technology and Innovation, (New York: McGraw-Hill 2004).

81. F. T. Rothaermel and A. M. Hess, Building Dynamic Capabilities: Innovation Driven by Individual-, Firm and Network-Level Effects, Organization Science. 18(6) (2007) 898-921.

82. F. T. Rothaermel and C. W. L. Hill, Technological discontinuities and complementary assets: A longitudinal study of industry and firm performance, Organization Science. 16 (2005) 52-70.

83. J. H. Tilton, International Diffusion of Technology: The Case of Semiconductors, (Washington, DC: Brookings Institution 1971).

84. D. B. Holm, K. Eriksson and J. Johanson, Creating value through mutual commitment to business network, Strategic Management Journal. 20 (1999) 467-486.
85. M. A. Peteraf, The cornerstones of competitive advantage: A resource-based view, Strategic Management Journal. 14 (1993) 179-191.

86. M. A. Hitt, L. Bierman, K. Shimizu and R. Kochhar, Direct and moderating effects of human capital on strategy and performance in professional service firms: A resource-based perspective, Academy of Management Journal. 44 (2001) 13-28.

87. T. H. Davenport and L. Prusak, Working knowledge: How organizations manage what they know, (Boston: Harvard Business School Press 1998).

88. J. Nahapiet and S. Ghoshal, Social capital, intellectual capital, and the organizational advantage, Academy of Management Review. 23 (1998) 242-266.

89. T. W. Schultz, Investment in human capital, American Economic Review. 51 (1961) 1-17.

90. M. A. Youndt, M. Subramaniam and S. A. Snell, Intellectual capital profiles: An examination of investments and returns, Journal of Management Studies. 41 (2004) 335-362.

91. R. D. Dewar and J. E. Dutton, The adoption of radical and incremental innovations: An empirical analysis, Management Science. 32 (1986) 1422-1433.

92. R. K. Chandy and G. J. Tellis, The incumbent's curse? Incumbency, size and radical product innovation, Journal of Marketing. 64(3) (2000) 1-17.

93. M. Tushman and P. Anderson, Technological discontinuities and organizational environments, Administrative Science Quarterly. 31 (1986) 439-465

94. W. J. Abernathy and K. Clark, Innovation: Mapping the winds of creative destruction, Research Policy. 14 (1985) 3-22.

95. M. Subramaniam and M. A. Youndt, The influence of Intellectual capital on the types of innovative capability, Academy of Management Journal. 48 (2005) 450-463.

96. T. E. Stuart and J. M. Podolny, Local search and the evolution of technological capabilities, Strategic Management Journal. Summer Special Issue 17 (1996) 21-38.

97. D. Leonard-Barton, Core capabilities and core rigidities: A paradox in managing new product development, Strategic Management Journal. 13 (1992) 111-126.

98. S. A. Snell and J. W. Dean, Integrated manufacturing and human resources management: A human capital perspective, Academy of Management Journal. 35 (1992) 467-504. 
99. J. G. March, Exploration and Exploitation in Organizational Learning, Organization Science. 2(1) (1991) 71-87.

100. Y. Al-Ansari, M. Altalib and M. Sardoh, Technology Orientation, Innovation and Business Performance: A Study of Dubai SMEs, The International Technology Management Review. 3(1) (2013) 1-11.

101. J. Sher Peter and P. Y. Yang, The effects of innovative capabilities and R\&D clustering on firm performance: The evidence of Taiwan's semiconductor industry, Technovation. 25 (2005) 33-43.

102. W. M. Cohen and D. A. Levinthal, Absorptive capacity: a new perspective on learning and innovation, Administrative Science Quarterly, 35(1) (1990) 128-152.

103. M. Nieto and P. Quevedo, Absorptive capacity, technological opportunity, knowledge spillovers, and innovative effort, Technovation. 25 (2005) 1141-1157.

104. W. Tsai, Knowledge transfer in intraorganizational networks: Effects of network position and absorptive capacity on business unit innovation and performance, Academy of Management Journal. 44(5) (2001) 9961004.

105. G. George, S. A. Zahra, K. K. Wheatley and R. Khan, The effects of alliance portfolio characteristics and absoprtive capacity on performance: a study of biotechnology firms, Journal of High Technology Management Research. 12(2) (2001) 205-227.

106. U. Lichtenthaler, Absorptive capacity, environmental turbulence, and the complementarity of organizational learning processes, Academy of Management Journal,. 52 (2009) 822-846.

107. T. C. Flatten, G. I. Greve and M. Brettel, Absorptive Capacity and Firm Performance in SMEs: The Mediating Influence of Strategic Alliance, European Management Review. 8 (2011) 137-152.

108. R. F. Hurley and G. T. M. Hult, Innovation, market orientation, and organizational learning: an integration and empirical examination, The Journal of Marketing. 62 (1998) 42- 54

109. N. M. Dixon, Organizational learning: a review of the literature with implications for HRD professionals, Human Resource Development. 3 (1992) 29-49.

110. C. Argyris and D. A. Schon, Organizational learning: a theory of action perspective, (MA: Addison-Wesley 1978).

111. J. Sinkula, W. Baker and T. Noordewier, A framework for market-based organizational learning: Linking values, knowledge, and behavior, Journal of the Academy of Marketing Science. 25 (1997) 305-318.

112. C. Moorman and A. S. Miner, Organizational improvisation and organizational memory, Academy of Management Review. 23(4) (1998) 698-723.

113. A.D. Ellinger, A. E. Ellinger, B. Yang and S. W. Howton, The Relationship between the learning organization concept and firms' financial performance: An empirical assessment, Human Resource Development Quarterly. 13(1) (2002) 5-21.

114. I. M. Prieto and E. Revilla, Learning capability and business performance: A non-financial and financial assessment, The Learning Organization. 13(2) (2006) 166-185.

115. M. J. Tippins and R. S. Sohi, IT competency and firm performance: Is organizational learning a missing link?, Strategic Management Journal. 24(8) (2003) 745-761.

116. B. A. Lukas, G. T. M. Hult and O. C. Ferrell, A theoretical perspective of the antecedents and consequences of organizational learning in marketing channels, Journal of Business Research. 36(3) (1996) 233- 244.

117. S. Calantone, Tamer Cavusgil and Yushan Zhao, Learning Orientation, firm innovation capability and firm performance, Industrial Marketing Management. 31(6) (2002) 515-524.

118. J. J. Mohr and S. Sengupta, Managing the paradox of inter-firm learning: The role of governance mechanisms, The Journal of Business \& Industrial Marketing. 17(4) (2002) 282-301.

119. J. W. C. Tomlinson, The joint venture process in international business: India and Pakistan, (Cambridge, MA: MIT Press 1970).

120. J. M. Geringer, Trends and traits of Canadian joint ventures, (Ottawa: Investment Canada 1990)

121. K. R. Harrigan, Managing for joint venture success, (Lexington, MA: Lexington Books 1986).

122. B. Kogut, Joint ventures: Theoretical and empirical perspectives, Strategic Management Journal. 9(4) (1988a) 319-332.

123. H. Mjoen, and S. Tallman, Control and performance in international joint ventures, Organization Science. 8 (1997) 257-274.

124. A. Parkhe, Messy research, methodological predispositions, and theory development in international joint ventures, Academy of Management Review. 18 (1993a) 227-268. 
125. B. Kogut, A Study of the life cycle of joint ventures, In Cooperative strategies in international business, eds. F.J. Contractor and P. Lorange, (Lexington, MA: Lexington Books 1988b).

126. A. C. Inkpen and S. C. Currall, S.C. International joint venture trust: An empirical examination. In Cooperative strategies: North American perspectives, eds. P.W. Beamish and J.P. Killing, Vol. 1 (San Francisco, CA: New Lexington Press 1997) pp. 308-334.

127. R. M. Kanter, Collaborative advantage: The art of alliances, Harvard Business Review. 72(4) (1994) 96108.

128. T. K. Das and Bing-Sheng Teng, Partner analysis and alliance performance, Scandinavian Journal of Management. 19 (2003) 279-308.

129. J. Christoffersen, A Review of Antecedents of International Strategic Alliance Performance: Synthesized Evidence and New Directions for Core Constructs, International Journal of Management Reviews. 15 (2013) 66-85.

130. P. Beamish, Joint ventures in LDCs: Partner selection and performance, Management International Review. 27(1) (1987)23-27.

131. F. Narin, E. Noma and R. Perry, R. Patents as indicators of corporate technological strength, Research Policy. 16(2-4) (1987) 143-155.

132. M. Trajtenberg, A penny for your quotes, The Rand Journal of Economics. 21(1) (1990) 172-187.

133. R. Cowan and N. Jonard, Knowledge portfolios and the Organization of Innovation, Academy of Management Review. 34 (2009) 320-342.

134. C. Ciborra, Alliances as learning experiments: cooperation, competition and change in high-tech industries, In Strategic Partnerships and the World Economy, eds. L. K. Mytelka, (London: Printer 1991) pp. 51-77.

135. J. H. Dyer and K. Nobeoka, Creating and managing a high performance knowledge-sharing network: the Toyota case, Strategic Management Journal. 21 (2000) 345-67.

136. A. C. Inkpen and M. M. Crossan, Believing is seeing: joint ventures and organizational learning, Journal of Management Studies. 32 (1995) 595-618.

137. P. Kale, H. Singh and H. Perlmutter, Learning and protection of proprietary assets in strategic alliances: Building relational capital, Strategic Management Journal. 21 (2000) 217-237.
138. T. Khanna, R. Gulati and N. Nohria, The dynamics of learning alliances: Competition, cooperation and relative scope, Strategic Management Journal. 19(3) (1998) 193-210.

139. R. Larsson, L. Bengtsson, K. Henriksson and J. Sparks, The interorganizational learning dilemma: Collective knowledge development in strategic alliances, Organization Science. 9(3) (1998) 285-305.

140. M. A. Lyles, Learning among joint-venture sophisticated firms, Management International Review. 28 Special Issue (1988) 85-98.

141. D. C. Mowery, J. E. Oxley B. S. Silverman, Technological overlap and inter-firm cooeration: implications of the resource-based view of the firm, Research Policy. 26 (1997) 421-438.

142. B. L. Simonin, The importance of collaborative knowhow: an empirical test of the learning organization, Academy of Management Journal. 40 (1997) 1150-1174.

143. B. L. Simonin, Ambiguity and the process of knowledge transfer in strategic alliances, Strategic Management Journal. 20 (1999) 595-623.

144. E. Fang, The Effect of Strategic Alliance Knowledge Complementarity on New Product Innovativeness in China, Organization Science. 22(1) (2011) 158-172.

145. D. C. Mowery, J. E. Oxley and B. S. Silverman, Technological overlap and inter firm cooperation: implications for the resource based view of the firm, Research Policy. 27 (1998) 507-523.

146. R. M. Grant, Towards a knowledge-based theory of the firm, Strategic Management Journal. 17 (1996) 109 122.

147. B. Nooteboom, Learning and innovation in organizations and economics, (Oxford: Oxford University Press 2000).

148. G. Ahuja and R. Katila, Technological acquisitions and the innovation performance of acquiring firms: A longitudinal study, Strategic Management Journal. 22 (2001)197-220.

149. R. U. Jiang, Q. T. Tao and M. D. Santoro, Alliance Portfolio Diversity and Firm Performance, Strategic Management Journal. 31 (2010) 1136-1144.

150. M. S. Lofstrom, Absorptive capacity in strategic alliances: Investigating the effects of individual's social and human capital on inter-firm learning, Organization Science Winter Conference Keystone Colorado (2000).

151. A. Arino, and J. de la Torre, Learning from failure: towards an evolutionary model of collaborative ventures, Organization Science. 9(3) (1998) 306-325. 
152. B. Anand and T. Khanna, Do firms learn to create value? The case of alliances, Strategic Management Journal Special Issue 21 (2000) 295-315.

153. P. Kale and H. Singh, Building alliance capabilities: A knowledge-based approach. Academy of Management Best Paper Proceedings, Chicago, IL (1999).

154. J. Child, Learning through Strategic Alliances, In Handbook of Organizational Learning and Knowledge, eds. J. Child and I. Nonaka (Oxford: Oxford University Press 2001) pp. 657-680

155. M. Lubatkin, J. Florin and P. Lane, Learning Together and Apart: A Model of Reciprocal Interfirm Learning, Human Relations. 54 (2001) 1353-1382.

156. D. C. Mowery and J. E. Oxley, Inward technology transfer and competitiveness: the role of national innovation systems, Cambridge Journal of Economics. 19 (1995) 67- 93.

157. A. Gambardella, Competitive advantages from in-house scientific research: the U.S. pharmaceutical industry in the 1980's, Research Policy. 21 (1992) 391-407.

158. P. J. Lane and M. Lubatkin, Relative absorptive capacity and inter organizational learning, Strategic Management Journal. 19 (1998) 461-477.

159. J. H. Dyer and H. Singh, The relational view: cooperative strategy and sources of interorganizational competitive advantage, Academy of Management Review. 23 (4) (1998) 660-679.

160. P. Koza Mitchell and A. Y. Lewin, The co-evolution of strategic alliances, Organization Science. 9(3) (1998) 285-305.

161. R. Gulati, Does familiarity breed trust? The implications of repeated ties for contractual choice in alliances, Academy of Management Journal. 38 (1995) 85-112.

162. A. Zaheer, B. McEvily and V. Perrone, Does trust matter? Exploring the effects of interorganizational and interpersonal trust on performance, Organization Science. 9 (1998) 141-159.

163. E. W. K. Tsang, D. T. Nguyen and M. K. Erramilli, Knowledge acquisition and performance of international joint ventures in a transition economy, Journal of International Marketing. 12(2) (2004) 82-103.

164. D. E. Westney, Domestic and foreign learning curves in managing international cooperative strategies, In Cooperative Strategies in International Business, eds. F.J. Contractor and P. Lorange (Lexington, MA: Lexington Books 1988) pp. 339-346.
165. A. Filley, R. House and S. Kerr, Managerial Process and Organizational Behavior 2nd Edition, (Glenview, IL: Scott Foresman 1976).

166. J. Kelly, Organizational Behavior: An Existential-System Approach, (Richard Irwin Inc 1974).

167. D. Minbaeva, T. Pedersen, I. Bjorkman, C. F. Fey and H. J. Park, MNC knowledge transfer, subsidiary absorptive capacity and HRM, Journal of International Business Studies. 34 (2003) 586-599.

168. G. Hamel, Competitive collaboration: Learning, power and dependence in international strategic alliances. The University Michigan: Unpublished dissertation (1990).

169. Y. Teramoto, F. J. Richter and N. Iwasaki, Learning to succeed: what European firms can learn from Japanese approaches to strategic alliances?, Creative and Innovation Management. 2(2) (1993) 114-121.

170. B. L. Simonin, An empirical investigation of the process of knowledge transfer in international strategic alliances, Journal of International Business Studies. 35 (2004) 407-427.

171. L. Argote and P. Ingram, Knowledge Transfer: A Basis for Competitive Advantage in Firms, Organizational Behavior and Human Decision Processes. 82(1) (2000) 150-169.

172. L. Argote, S. L. Beckman and D. Epple, The persistence and transfer of learning in industrial settings, Management Science. 36 (1990) 140-154.

173. P. Almeida and B. Kogut, Localization of knowledge and the mobility of engineers in regional networks, Management Science. 45 (1999) 905-917.

174. J. A. C. Baum and P. Ingram, Survival-enhancing learning in the Manhattan hotel industry 1898-1980, Management Science. 44 (1998) 996-1016.

175. M. T. Hansen, Knowledge networks: Explaining effective knowledge sharing in multiunit companies, Organization Science. 13 (2002) 232-248.

176. T. Kostova, Transnational transfer of strategic organizational practices: A contextual perspective, Academy of Management Review. 24 (1999) 306-324.

177. S. K. Muthusamy and A. W. Margaret, Learning and knowledge transfer in Strategic Alliances: A social exchange view, Organization Studies. 26(3) (2005) 415441.

178. B. Kogut and U. Zander, Knowledge of the firm, combinative capabilities, and the replication of technology, Organization Science. 3 (1992) 383-397. 
179. J. C. Spender, Limits to learning from the west, The International Executive. 34 September/October (1992) 389-410.

180. M. Granovetter, Economic Action and Social Structure: The Theory of Embeddedness, American Journal of Sociology. 91(3) (1985) 481-510.

181. M. Granovetter, The Strength of Weak Ties, American Journal of Sociology. 78 (1973) 1360-1380.

182. E. Anderson and B. Weitz, Determinants of Continuity in Conventional Industrial Channel Dyads, Marketing Science. 8(4) (1989) 310-323.

183. L. Cummings, and P. Bromiley, Trust in Organizations: Frontiers of Theory and Research, (California: Sage publications 1996).

184. R. Axelrod, The Evolution of Cooperation, (NY: Basic Books 1984).

185. Y. L. Doz and G. Hamel, Alliance Advantage, The Art of Creating Value through Partnering, (Cambridge, MA: Harvard Business School Press 1998).

186. D. Krackhardt, The Strength of Strong Ties: The Importance of Philos, In Organizations, In Networks and Organizations: Structure, Form and Action, eds N. Nohria and R. Eccles, (Boston: Harvard Business School Press 1992) pp. 216-239.

187. J. Nahapiet, Managing Relationships With Global Clients: Value Creation Through Cross-border Networks, Paper presented at the 16th Annual Conference of Strategic Management Society Phoenix AZ (1996)

188. R. R. Nelson and S. C. Winter, An Evolutionary Theory of Economic Change, (Boston: Belknap Press of Harvard University Press 1982).

189. W. H. Starbuck, Learning by knowledge intensive firms, Journal of Management Studies. 29 (1992) 713-740.

190. B. Uzzi, The sources and consequences of embeddedness for the economic performance of organizations: The network effect, American Sociological Review. 61 (1996) 674-698.

191. A. Madhok, Revisiting multinational firms' tolerance for joint ventures: a trust based approach, Journal of International Business Studies. 26 (1995) 117-38.

192. A. Parkhe, Strategic alliance structuring: A game theory and transaction cost examination of interfirm cooperation, Academy of Management Journal. 36 (1993b) 794-829.

193. B. B. Nielsen and S. Nielsen, Learning and Innovation in International Strategic Alliances: An Empirical Test of the Role of Trust and Tacitness, Journal of Management Studies. 46:6 September (2009) 1031-1056

194. P. J. Buckley, K. W. Glaister, E. Klijn and H. Tan, Knowledge accession and knowledge acquisition in strategic alliances: The impact of supplementary and complementary dimensions, British Journal of Management. 20(4) (2009) 598-609.

195. R. Krishnan, X. Martin and N. G. Noorderhaven, When does trust matter to alliance performance?, Academy of Management Journal. 49(5) (2006) 894-917.

196. B. McEvily and A. Zaheer, Does trust still matter? Research on the role of trust in interorganizational exchange, In Handbook of trust research, eds. R. Bachmann and A. Zaheer (Cheltenham: Elgar 2006) pp. 280-300

197. B. B. Nielsen, Determining international strategic alliance performance: A multidimensinoal approach, International Business Review. 16 (2007) 337-361

198. M. J. Robson, C. S. Katsikeas and D. C. Bello, Drivers and Performance outcomes of Trust in International Strategic Alliances: The Role of Organizational Complexity, Organization Science. 19(4) (2008) 647665 .

199. M. Sako, Does trust improve business performance?, In Trust within and between organization, eds. C. Lane and R. Bachmann, (Oxford: Oxford University Press 1998) pp. 88-117.

200. Mohr, A., and Puck, J. (2013). Revisiting the Trustperformance Link in Strategic Alliances, Management International Review, Volume 53, Issue 2, 269-289.

201. I. Nonaka and H. Takeuchi, The Knowledge Creating Company. (New York: Oxford University Press 1995)

202. R. J. Boland and R. V. Tenkasi, Perspective making and perspective taking in communities of knowledge, Organization Science. 6 (1995) 350-372.

203. R. Dearborn and H. A. Simon, Selective perception in executives, Sociometry. 21 (1958) 140-144.

204. M. K. Singley, and J. R. Anderson, The Transfer of Cognitive Skill, (Cambridge, MA: Harvard Press 1989).

205. H. Zhand, C. Shu, Xu Jiang and A. J. Malter, Managing Knowledge for Innovation: The Role of Cooperation, Competition, and Alliance Nationality, Journal of International Marketing. 18(4) (2010) 74-94.

206. Xu Jiang and Yuan Li, The relationship between organizational learning and firm's financial performance in strategic alliances: A contingency approach, Journal of World Business. 43 (2008) 365-379. 
207. R. N. Langlois, Transaction-cost economics in real time, Industrial and Corporate Change. 1 (1992) 99-127.

208. C. Chen, The effects of knowledge attribute, alliance characteristics, and absorptive capacity on knowledge transfer performance, $R \& D$ Management. 34 (2004) 311-321.

209. D. Lavie and L. Rosenkopf, Balancing exploration and exploitation in alliance formation, Academy of Management Journal. 49 (2006) 797-818.

210. B. Noteboom, W. VanHaverbeke, G. Duysters, V. Gilsing and A. Van den Oord, Optimal cognitive distance and absorptive capacity, Research Policy 36(7) September (2007) 1016-1034.

211. C. Lin, Ya-Jung Wub, C. C. Chang, W. Wang and Cheng-Yu Lee, The Alliance Innovation Performance of R\&D Alliances- The Absorptive Capacity Perspective, Technovation. 32 (2012) 282-292.

212. Y. S. Chen, M. J. J. Lin and C. H. Chang, The Positive Effects of Relationship Learning and Absorptive Capacity on Innovation Performance and Competitive Advantage in Industrial Markets, Industrial Marketing Management. 38(2) (2009) 152-158.

213. K. H. Tsai, Collaborative Networks and Product Inovation Performance: Towards a Contingency Perspective, Research Policy. 38(5) (2009) 765-778.

214. T. Stuart, Inter organizational Alliances and the Performance of firms: A study of growth and innovation rates in a high technology industry, Strategic Management Journal. 21 (2000) 791-811.

215. G. Ahuja, The duality of collaboration: Inducements and opportunities in the formation of interfirm linkages, Strategic Management Journal. 21 (2000b) 317-343.
216. H. Li and K. Atuahene-Gima, The adoption of agency business activity, product innovation, and performance in Chinese technology ventures, Strategic Management Journal. 23 (2002) 469-490.

217. T. E. Stuart, Network positions and propensities to collaborate: An investigation of strategic alliance formation in a high-technology industry, Administrative Science Quarterly. 43 (1998) 668-698.

218. K. R. Harrigan, Managing for joint venture success, (New York: Praeger 1985).

219. Yu-An Huang, C. Lin, Y. C. Liu and Tung Mei-Lien, The Effects of IT Resource Alignment and Organizational Dynamism on Alliance Performance in Hemodialysis Centers, The International Technology Management Review. 3(2) (2013) 105-115.

220. R. P. Nielsen, Cooperative strategy, Strategic Management Journal. 9 (1988) 475-492.

221. K. J. Hladik, International Joint Ventures. (Lexington, MA: Lexington Books 1985).

222. K. J. Hladik, R\&D and international joint ventures, In Cooperative Strategies in International Business, eds. F.J. Contractor and P. Lorange, (Lexington, MA: Lexington Books 1988) pp. 187-205.

223. S. H. Chen, Hong-Tau Lee and Yi-Fen Wu, Applying ANP approach to partner selection for strategic alliance, Management Decision. 46(3) (2008) 449-465.

224. S. H. Chen, P. W. Wang, C. M. Chen and H. T. Lee, An analytic hierarchy process approach with linguistic variables for selection of an R\&D strategic alliance partner, Computers and Industrial Engineering. 58 (2010) 278-287. 